\title{
The Effect of Various Inactivating Agents on the Viral and Ribonucleic Acid Infectivities of Foot-and-Mouth Disease Virus and on its Attachment to Susceptible Cells
}

\author{
By F. BROWN, B. CARTWRIGHT AND DOREEN L. STEWART \\ Research Institute (Animal Virus Diseases), Pirbright, Surrey
}

(Received 22 August 1962)

\begin{abstract}
SUMMARY
Foot-and-mouth disease (FMD) virus was partially inactivated by several methods: incubation with dilute formaldehyde or acetylethyleneimine, ultraviolet (U.V.) irradiation, heating, or by mixing with type specific antiserum, trypsin or extracts from cells susceptible to the virus. The serological properties of the treated virus preparations were studied by complement-fixation and agar diffusion tests and their content of infective ribonucleic acid (RNA) determined by phenol extraction. The ability of the treated preparations to attach to susceptible cultivated pig kidney cells was examined. The decrease in viral infectivity when FMD virus was treated with formaldehyde or acetylethyleneimine, U.V., or heat at $25^{\circ}$ or $37^{\circ}$ was proportional to the loss of infective RNA, with little impairment of its serological properties or its ability to attach to susceptible cells. In contrast, loss of viral infectivity on mixing with antiserum, trypsin or cell extracts was due to the failure of the virus to attach to susceptible cells; the viral RNA is still present in an infective form in these mixtures.
\end{abstract}

\section{INTRODUCTION}

Now that several stages can be recognized in the multiplication of animal viruses the points at which this multiplication can be impeded or inhibited may be examined in more detail. The infectivity of many viruses can be considerably decreased by heating at $56^{\circ}$ or by treatment with dilute formaldehyde or by mixing with the specific antiserum. It is not known, however, whether these processes result in the loss of infectivity of the nucleic acid core of the virus or whether the inactivation is due to some blocking action which prevents the virus from attaching to the susceptible cell or from releasing its nucleic acid when it does attach. This is fundamental to the study of virus multiplication and is also pertinent in considering whether a formalinized (inactivated) vaccine is in fact non-infective, i.e. whether its nucleic acid has been inactivated. To answer some of these questions for footand-mouth disease (FMD) virus the effect of several inactivating procedures on the viral and RNA infectivities and on the serological properties of the virus was studied, together with the ability of the inactivated virus to attach to cells able to support the growth of the virus. 


\section{METHODS}

Virus and $R N A$ preparations. Strains 1 (type 0 ) and 997 (type C) of FMD virus were used. The first is maintained by intradermal inoculation of the metatarsal pads of guinea pigs. The fluid collected from the local vesicles which develop is highly infectious for unweaned mice (about $10^{9.5} \mathrm{ID} \mathrm{50} / \mathrm{ml}$.). Strain 997 has been passaged more than 100 times in monolayers of pig kidney cells and the virus was routinely harvested when the cells had been stripped from the glass by its action. Infective RNA was prepared from the virus suspensions by the cold phenol method (Gierer \& Schramm, 1956).

Titration of virus and $R N A$. Virus was titrated either by intraperitoneal inoculation of groups of 7 day mice (Skinner, 1951) or by the plaque method in monolayer cultures of pig kidney cells (Sellers, 1955) or occasionally by the metabolic inhibition test (Martin \& Chapman, 1961). RNA from strain 1 was assayed by intracerebral inoculation of 7 day unweaned mice (Brown, Sellers \& Stewart, 1958) and that from strain 997 in pig kidney cell monolayers (Brown \& Stewart, 1959). Freedom of the RNA from residual virus was ensured by showing that the infectivity was destroyed by the addition of a trace of ribonuclease.

Examination of serological properties of virus suspensions. The serological properties were studied by complement-fixation and by diffusion in agar. The complement-fixing activity of FMD virus suspensions is distributed between the infective $25 \mathrm{~m} \mu$ component and the accompanying non-infective $7 \mathrm{~m} \mu$ component. This difference in size allows ready separation by ultracentrifugation so that an assessment of the proportion of each component in a suspension can be obtained by a combination of ultracentrifugation and complement-fixation. In these experiments the virus samples were spun for $1 \mathrm{hr}$. at $30,000 \mathrm{rev} . / \mathrm{min}$. $(60,000 \mathrm{~g}$ mean) in the $\mathrm{L} 40$ head of the Spinco Ultracentrifuge and the complement-fixing activity of the top $8 \mathrm{ml}$. and bottom $2 \mathrm{ml}$. compared with that of the initial suspension. Brooksby's (1952) method was used for the titration of the complement-fixing activity of the suspensions. In this method equal amounts of antigen and antiserum dilutions are allowed to react with different amounts of complement and the $\mathbf{5 0} \%$ haemolytic end-point calculated by the use of probits.

Similarly, an approximate estimation of the relative amounts of the two virus components can be made by the use of the agar gel diffusion test when the concentration of the two components is sufficiently high (Brown \& Crick, 1958). The vesicular fluid from guinea pigs infected with virus (strain 1) can be used directly for agar diffusion but the tissue culture harvests (strain 997) used in this work required concentration (e.g. with polyethylene glycol) before they could be examined in this way.

Adsorption of virus to cultivated pig kidney cells. Suspensions were prepared by removing the pig kidney cells from primary monolayer cultures with a mixture of ethylenediaminetetra-acetic acid (EDTA) and trypsin ( $0.01 \%$ of each) in phosphate buffered saline free from $\mathrm{Ca}^{2+}$ and $\mathrm{Mg}^{2+}$. The cells were then washed several times in phosphate buffered saline. Virus was added in the proportion of one infective unit to one cell and the mixture incubated at $37^{\circ}$. With fully infective virus this results in the adsorption of more than $90 \%$ of the virus and the breakdown of the adsorbed $25 \mathrm{~m} \mu$ infective component into its RNA and $7 \mathrm{~m} \mu$ components (Brown, 
Cartwright \& Stewart, 1961). The events following addition of inactivated virus preparations were ascertained by: $(a)$ estimating the infective RNA in the inocula, unadsorbed supernatant and cells; $(b)$ examining the nature of the adsorbed virus antigen by complement-fixation and agar diffusion tests. Although mixing the virus with pig kidney cells results in the removal of about $90 \%$ of the complementfixing activity from the inoculum, the cells do not fix complement when mixed with the type specific antiserum. When the cells are extracted with ether, about $50 \%$ of the adsorbed virus antigen can then be recovered.

\section{RESULTS}

\section{Action of formaldehyde and acetylethyleneimine}

Virus suspensions were inactivated by treating with 1/5000 formaldehyde ( = 1/2000 dilution of $40 \%$ formalin solution) at $\mathrm{pH} 7 \cdot 6$ and $25^{\circ}$ for various periods. The inactivation was interrupted at intervals by adding excess sodium bisulphite. Similar partially inactivated preparations were obtained by treatment with $0.05 \%$ $(\mathrm{v} / \mathrm{v})$ acetylethyleneimine at $37^{\circ}$ except that in this case sodium thiosulphate was used to stop the inactivation process. Each preparation was then dialysed before extraction of the infective RNA and examination of its serological properties.

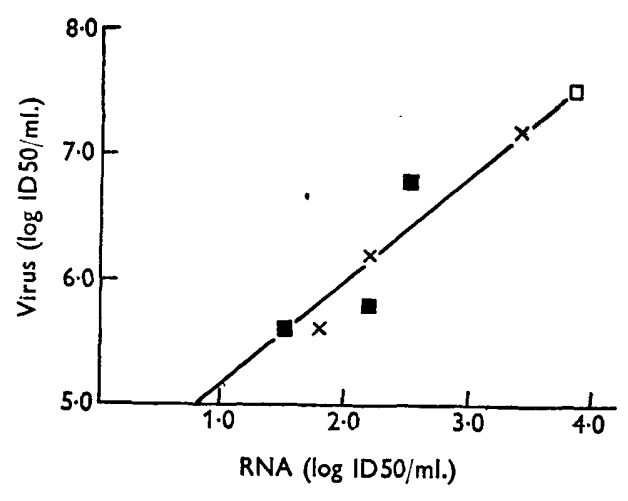

Fig. 1

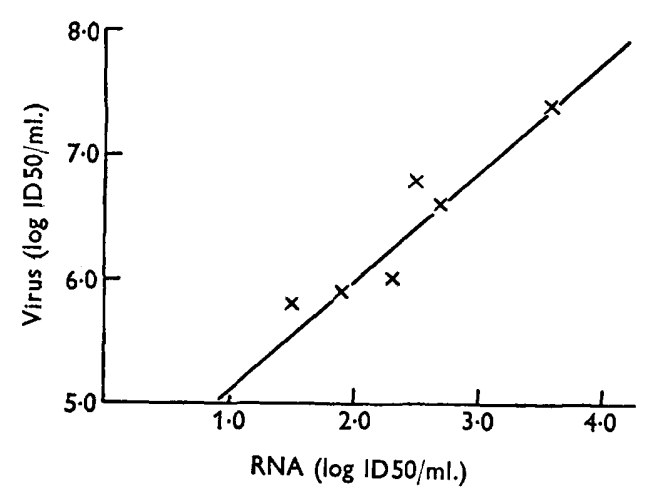

Fig. 2

Fig. 1. Effect of dilute formaldehyde $(x)$ and acetylethyleneimine $(\square)$ on the infectivity of FMD virus and the RNA in the virus (initial virus ( $\square)$ )).

Fig. 2. Effect of ultraviolet irradiation on the infectivity of FMD virus and the RNA in the virus.

The yields of infective RNA obtained from the series of partially inactivated preparations were proportional to the residual virus infectivity (Fig. 1). Neither inactivation procedure led to any alteration in the total complement-fixing activity of the virus suspensions, even when carried on to complete inactivation. In addition, ultracentrifugation at $30,000 \mathrm{rev} . / \mathrm{min}$. still resulted in the deposition of about $70 \%$ of the complement-fixing activity into the bottom $2 \mathrm{ml}$. of the tube. Similarly, two precipitin lines, corresponding to the 25 and $7 \mathrm{~m} \mu$ components of the virus, were obtained in the agar diffusion test with the inactivated preparations as well as with the initial suspension. 


\section{Action of ultraviolet radiation}

Preparations of the virus were U.V.-irradiated for various intervals with a Hanovia chromatolite; this emits radiation mainly at a wavelength of $2537 \AA$., which would be expected to inactivate the RNA rather than the protein part of the virus. Samples of irradiated material were removed at intervals and titrated for residual virus and the amount of residual infective RNA estimated by extraction with phenol. As with the formaldehyde and acetylethyleneimine inactivated preparations, the decrease in virus titre was accompanied by a corresponding decrease in the infective RNA (Fig. 2). Similarly, the inactivated preparations had serological properties which were indistinguishable from the starting material in the complement fixation and agar diffusion tests.

Table 1. Effect of incubating $F M D$ virus (strain 1) and viral RNA suspensions at $25^{\circ}$ and $37^{\circ}$ on their infectivity

\begin{tabular}{|c|c|c|}
\hline & $\begin{array}{l}\text { Virus titre } \\
(\log . \text { ID 50/ml.) }\end{array}$ & $\begin{array}{l}\text { RNA titre } \\
(\log . \text { ID 50/ml. })\end{array}$ \\
\hline Initial suspension in $0 \cdot 04 \mathrm{M}-\mathrm{phosphate}(\mathrm{pH} 7 \cdot 6)$ & $8 \cdot 3$ & $4 \cdot 3$ \\
\hline Suspension at $25^{\circ}$ for $24 \mathrm{hr}$. & $\mathbf{7 \cdot 3}$ & $3 \cdot 4$ \\
\hline $\begin{array}{l}\text { Suspension at } 25^{\circ} \text { for } 24 \mathrm{hr} \text {. in } 0 \cdot 1 \% \text { sodium dodecyl- } \\
\text { sulphate }\end{array}$ & $\mathbf{7 \cdot 2}$ & $\mathbf{3 \cdot 2}$ \\
\hline Suspension at $37^{\circ}$ for $8 \mathrm{hr}$ & $6 \cdot 9$ & $\mathbf{3} \cdot \mathbf{1}$ \\
\hline $\begin{array}{l}\text { Suspension at } 37^{\circ} \text { for } 8 \mathrm{hr} \text {. in } 0 \cdot 1 \% \text { sodium dodecyl- } \\
\text { sulphate }\end{array}$ & 6.7 & $3 \cdot 1$ \\
\hline Initial RNA & - & $\mathbf{4} \cdot \mathbf{3}$ \\
\hline $\begin{array}{l}\mathrm{RNA} \text { at } 25^{\circ} \text { for } 24 \mathrm{hr} \text {. in } 0 \cdot 1 \% \text { sodium dodecyl- } \\
\text { sulphate }\end{array}$ & - & $\mathbf{2 \cdot 3}$ \\
\hline RNA at $37^{\circ}$ for $8 \mathrm{hr}$. in $0.1 \%$ sodium dodecylsulphate & - & 2.5 \\
\hline
\end{tabular}

\section{Action of heat}

The effects of prolonged heating at $25^{\circ}$ and $37^{\circ}$ were studied. Some of the results obtained when FMD virus is heated at $56^{\circ}$ have already been reported (Brown \& Cartwright, 1961). These will be referred to in the Discussion, to illustrate the marked differences in the results obtained at the different temperatures. About $90 \%$ of the initial infectivity was lost in $24 \mathrm{hr}$. at $25^{\circ}$ and the yield of infective RNA obtained from the heated virus was correspondingly lower (Table 1). Heating virus suspensions at $37^{\circ}$ also caused a decrease in the virus titre and amount of infective RNA obtained from them. When the infective RNA was first extracted from the virus before heating at $25^{\circ}$ or $37^{\circ}$, and protected from traces of residual ribonuclease by the addition of $0 \cdot 1 \%$ sodium dodecyl sulphate, its infectivity was lost rather more rapidly than that of the virus (Table 1). Virus suspensions held at $25^{\circ}$ and $37^{\circ}$ for periods of time which resulted in the loss of more than $99.9 \%$ of the initial infectivity, showed the same pattern of two precipitin lines on diffusion in agar and possessed the same properties in the ultracentrifuge as the initial virus, thus indicating that the effect of heating was on the RNA core of the virus rather than on the protein coat. 


\section{Action of trypsin, cell debris and viral antiserum}

Addition of crystalline trypsin to the tissue culture virus at a concentration of $1 \mathrm{mg} . / \mathrm{ml}$. resulted in a decrease in virus titre of about 2 logs. With smaller concentrations the decrease in titre was less but was about $1 \log (90 \%)$ even with $0.01 \mathrm{mg}$. trypsin/ml. Despite the decrease, as much infective RNA could be obtained from the virus + trypsin mixtures as from the initial virus suspension (Table 2).

Table 2. Effect of mixing FMD virus (strain 997) with trypsin, viral antiserum and cell extracts on the viral and $R N A$ infectivity

$\begin{array}{lcc}\text { Addition to virus } & \begin{array}{c}\text { Virus titre } \\ \text { (log. ID 50/ml.) }\end{array} & \begin{array}{c}\text { RNA titre } \\ \text { (log. ID 50/ml.) }\end{array} \\ \text { Nil } & \mathbf{7 \cdot 0} & \mathbf{2 \cdot 7} \\ \text { Trypsin } & 4 \cdot 9 & \mathbf{2 \cdot 7} \\ \text { Trypsin + EDTA } & 4 \cdot 8 & - \\ \text { Trypsin + Arcton 113 } & 4 \cdot 9 & - \\ \text { Antiserum } & 1 \cdot 5 & \mathbf{2 \cdot 5} \\ \text { Antiserum + Arcton } 113 & \mathbf{7 \cdot 1} & - \\ \text { Cell extract } & \mathbf{5 \cdot 1} & \mathbf{2 \cdot 6} \\ \text { Cell extract + EDTA } & \mathbf{6 . 9} & -\end{array}$

A similar loss in virus infectivity without loss of infective RNA occurred when the virus was added to cell extracts prepared by grinding cultivated pig kidney cells in a mortar (Brown, Cartwright \& Stewart, 1962). In these experiments, however, the virus infectivity could be recovered by the addition of EDTA, which chelates $\mathrm{Ca}^{2+}$ essential for the attachment of FMD virus to pig kidney cells. Similar treatment of the virus + trypsin mixtures with EDTA did not lead to recovery of virus infectivity. Treatment of the mixture with 'Arcton 113' (Trifluorotrichlorethane, I.C.I.) also failed to recover the virus infectivity.

The infectivity of FMD virus suspensions can be considerably decreased by mixing them with homotypic antiserum from guinea pigs or cattle. Here, too, as much infective RNA was obtained from the virus + antiserum mixtures as from the initial virus suspensions (Table 2). In these experiments, however, Arcton treatment led to full recovery of the virus infectivity (Brown \& Cartwright, 1960).

Fate of inactivated virus preparations added to susceptible cultivated pig kidney cells

When infective tissue culture virus is added to cultivated pig kidney cells in the proportion of one infective unit per cell, the virus is rapidly adsorbed and engulfed by the cells; this is followed by disruption of the engulfed virus into its RNA and $7 \mathrm{~m} \mu$ protein components (Brown et al. 1961). Virus suspensions inactivated with formaldehyde and acetylethyleneimine or by heating at $25^{\circ}$ or $37^{\circ}$ were adsorbed as efficiently as the untreated virus (Table 3). The cells did not fix complement when mixed with viral antiserum, although much of the complement-fixing activity of the inoculum had been adsorbed by the cells. These results suggest that the inactivated virus preparations were engulfed by the cells and were thus not available for reaction with antiserum.

As with cells which had been mixed with untreated virus preparations, complement-fixing antigen could be recovered by ether extraction of cells which had 
adsorbed virus preparations inactivated by acetylethyleneimine and heat. Here too, the recovered complement-fixing antigen was not deposited by centrifugation at $30,000 \mathrm{rev} . / \mathrm{min}$. for $1 \mathrm{hr}$. in the L 40 head of the Spinco ultracentrifuge, indicating that these inactivated virus preparations had been disrupted by the cells (Table 3 ). In contrast to these observations, cells which had adsorbed virus inactivated by formaldehyde did not yield any complement-fixing antigen on extraction with ether, suggesting that such virus attaches to a different, presumably non-lipid, cellular constituent.

Virus partially inactivated by mixing with specific antiserum, cell extracts or trypsin was not adsorbed by the normally susceptible pig kidney cells. This was

Table 3. Adsorption by cultivated pig kidney cells of FMD virus (strain 997) inactivated by formaldehyde, acetylethyleneimine or incubation at $37^{\circ}$

\begin{tabular}{|c|c|c|c|c|}
\hline \multirow[b]{2}{*}{ Treatment } & \multirow[b]{2}{*}{ Sample } & \multirow{2}{*}{$\begin{array}{l}\text { Virus titre } \\
(\log \text { ID 50/ } \\
\text { ml.) }\end{array}$} & \multicolumn{2}{|c|}{$\begin{array}{l}\text { ml. } 1 / 30 \text { complement } \\
\text { fixed by } 1 \mathrm{ml} \text {. antigen }\end{array}$} \\
\hline & & & Total & Top $8 \mathrm{ml}$. \\
\hline None & $\begin{array}{l}\text { Initial virus } \\
\text { Unadsorbed virus } \\
\text { Cells } \\
\text { Cells extracted with ether }\end{array}$ & $\begin{array}{l}7 \cdot 0 \\
5 \cdot 0 \\
4 \cdot 5 \\
4 \cdot 3\end{array}$ & $\begin{array}{l}0 \cdot 80 \\
0 \cdot 20 \\
\mathrm{Nil} \\
0 \cdot 27\end{array}$ & $\frac{0 \cdot 25}{-}$ \\
\hline Formaldehyde & $\begin{array}{l}\text { Initial virus } \\
\text { Unadsorbed virus } \\
\text { Cells } \\
\text { Cells extracted with ether }\end{array}$ & $\begin{array}{c}\text { Non-infective } \\
- \\
-\end{array}$ & $\begin{array}{l}0 \cdot 80 \\
0 \cdot 17 \\
\text { Nil } \\
\text { Nil }\end{array}$ & $\begin{array}{l}0 \cdot 17 \\
- \\
-\end{array}$ \\
\hline Acetylethyleneimine & $\begin{array}{l}\text { Initial virus } \\
\text { Unadsorbed virus } \\
\text { Cells } \\
\text { Cells extracted with ether }\end{array}$ & $\begin{array}{c}\text { Non-infective } \\
- \\
- \\
-\end{array}$ & $\begin{array}{l}0 \cdot 73 \\
0 \cdot 17 \\
\text { Nil } \\
0 \cdot 28\end{array}$ & $\begin{array}{c}0 \cdot 15 \\
\overline{0 \cdot 28}\end{array}$ \\
\hline Incubation at $37^{\circ}$ & $\begin{array}{l}\text { Initial virus } \\
\text { Unadsorbed virus } \\
\text { Cells } \\
\text { Cells extracted with ether }\end{array}$ & $\begin{array}{l}\text { Non-infective } \\
- \\
- \\
-\end{array}$ & $\begin{array}{l}0 \cdot 84 \\
0 \cdot 16 \\
\text { Nil } \\
0 \cdot 39\end{array}$ & $\frac{0.23}{-}$ \\
\hline
\end{tabular}

Table 4. Reaction with cultivated pig kidney cells of virus (strain 997) inactivated by mixing with antiserum, trypsin or pig kidney cell extracts

\begin{tabular}{|c|c|c|c|}
\hline Treatment & Sample & $\begin{array}{l}\text { Virus titre } \\
\text { (log. ID 50/ } \\
\text { ml.) }\end{array}$ & $\begin{array}{l}\text { RNA titre } \\
\text { (log. ID 50/ } \\
\text { ml.) }\end{array}$ \\
\hline None & $\begin{array}{l}\text { Initial virus } \\
\text { Unadsorbed virus } \\
\text { Cells }\end{array}$ & $\begin{array}{l}7 \cdot 0 \\
5 \cdot 0 \\
4 \cdot 5\end{array}$ & $\begin{array}{l}2 \cdot 7 \\
0 \cdot 5 \\
2 \cdot 5\end{array}$ \\
\hline Type specific antiserum & $\begin{array}{l}\text { Virus-serum mixture } \\
\text { Unadsorbed mixture } \\
\text { Cells }\end{array}$ & 1.5 & $\begin{array}{c}\mathbf{2 \cdot 5} \\
\mathbf{2 \cdot 5} \\
\text { None } \\
\text { detected }\end{array}$ \\
\hline Trypsin & $\begin{array}{l}\text { Virus-trypsin mixture } \\
\text { Unadsorbed mixture } \\
\text { Cells }\end{array}$ & $\begin{array}{l}4 \cdot 9 \\
3 \cdot 5 \\
3 \cdot 0\end{array}$ & $\begin{array}{l}2 \cdot 7 \\
2 \cdot 5 \\
0 \cdot 5\end{array}$ \\
\hline Cell extracts & $\begin{array}{l}\text { Virus-cell extract mixture } \\
\text { Unadsorbed mixture } \\
\text { Cells }\end{array}$ & $\begin{array}{l}5 \cdot 1 \\
3 \cdot 3 \\
2 \cdot 9\end{array}$ & $\begin{array}{l}2 \cdot 6 \\
2 \cdot 3 \\
0 \cdot 7\end{array}$ \\
\hline
\end{tabular}


ascertained by extracting samples of the inocula, unadsorbed supernatant fluids and cells with phenol after incubation of the mixtures with the pig kidney cells. The yields of infective RNA from each fraction (Table 4) indicate that the decrease of virus infectivity was due to non-attachment of virus to the cells.

It was considered possible that $1 \mathrm{mg}$. trypsin/ml. would affect the surface proteins of cultivated pig kidney cells, thus influencing their adsorptive properties. Suspensions of the cells were, therefore, held for $15 \mathrm{~min}$. in trypsin solutions of this concentration, and then deposited in the centrifuge and mixed with virus. The treated cells adsorbed virus as efficiently as untreated cells and also produced as much virus when subsequently incubated at $37^{\circ}$.

The virus + trypsin complex was deposited as a pellet when centrifuged at $30,000 \mathrm{rev} . / \mathrm{min}$. for $150 \mathrm{~min}$. in the $\mathrm{L} \mathbf{4 0}$ head of the Spinco Ultracentrifuge. The pellet was readily suspended in phosphate buffered saline and yielded as much infective RNA as the initial virus when extracted with phenol. In some experiments the resuspended pellet was added to pig kidney cells; the RNA-containing material did not adsorb to these cells.

\section{DISCUSSION}

Although FMD virus can be inactivated in several ways, the mechanisms of these inactivations have not been previously examined in any detail. Our experiments show that dilute formaldehyde or acetylethyleneimine or U.V.-radiation destroy the infectivity of the RNA core of the virus. The protein coat of the virus and the proportions of the 25 and $7 \mathrm{~m} \mu$ components are unaffected by these treatments, as judged by complement-fixation and agar diffusion tests. More important is the fact that these inactivated preparations are taken up by susceptible cultivated pig kidney cells as efficiently as the untreated virus.

Virus inactivated by prolonged incubation at $25^{\circ}$ or $37^{\circ}$ also loses its RNA infectivity without any apparent change in the properties of the protein coat or alteration in the proportions of the 25 and $7 \mathrm{~m} \mu$ components. This result is in striking contrast to the effect of heating the virus at $56^{\circ}$. At this temperature, the $25 \mathrm{~m} \mu$ infective component is rapidly broken down into its infective RNA and $7 \mathrm{~m} \mu$ protein sub-units (Bachrach, 1961; Brown \& Cartwright, 1961) and as much infective RNA can be obtained by this treatment as by extracting the virus with phenol. The loss of RNA infectivity on prolonged incubation of the virus at $25^{\circ}$ and $37^{\circ}$ is probably due to heat denaturation rather than the action of environmental ribonuclease on the RNA core of the virus following rupture of the protein coat at some point, because the loss of RNA infectivity also occurs in the presence of sodium dodecyl sulphate, which inhibits the action of the enzyme. Nakamura (1961), working with mouse encephalomyelitis virus, also concluded that U.V. inactivation of the virus is due to destruction of the RNA whereas heat inactivation at $56^{\circ}$ is due to destruction of the protein coat and not the RNA.

The loss of virus infectivity when FMD virus suspensions are mixed with cell extracts, trypsin or homotypic antiserum does not result in any loss of RNA infectivity. The loss is due to failure of the virus to attach to susceptible cells. In fact, virus can be recovered quantitatively from the mixtures with cell extracts and antiserum by treatment with EDTA and Arcton 113, respectively. So far it has not been possible to recover the inactivated virus from virus + trypsin mixtures, 
suggesting that the site on the virus protein coat necessary for attachment to cells has been hydrolysed by the enzyme, thus preventing attachment to the susceptible cell. This is being further investigated.

\section{REFERENCES}

Bachrach, H. L. (1961). Thermal degradation of foot-and-mouth disease virus into infectious ribonucleic acid. Proc. Soc. exp. Biol., N.Y. 107, 610.

Brookssy, J. B. (1952). The technique of complement fixation in foot-and-mouth disease research. A.R.C. Rep. Ser. no. 12.

Brown, F. \& Cartwright, B. (1960). Purification of the virus of foot-and-mouth disease by fluorocarbon treatment and its dissociation from neutralizing antibody. J. Immunol. $85,309$.

Brown, F. \& Cartwright, B. (1961). Dissociation of foot-and-mouth disease virus into its nucleic acid and protein components. Nature, Lond. 192, 1163.

Brown, F., Cartwright, B. \& Stewart, D. L. (1961). Mechanism of infection of pig kidney cells by foot-and-mouth disease virus. Biochim. biophys. Acta, 47, 172.

Brown, F., Cartwright, B. \& Stewart, D. L. (1962). Further studies on the infection of pig kidney cells by foot-and-mouth disease virus. Biochim. biophys. Acta, 55, 768 .

Brown, F. \& Crick, J. (1958). Application of agar gel precipitin tests to the study of the virus of foot-and-mouth disease. Virology, $5,133$.

Brown, F., Sellers, R. F. \& Stewart, D. L. (1958). Infectivity of ribonucleic acid from mice and tissue culture infected with the virus of foot-and-mouth disease. Nature, Lond. $182,535$.

Brown, F. \& Stewart, D. L. (1959). Studies with infective ribonucleic acid from tissues and cell cultures infected with the virus of foot-and-mouth disease. Virology, 7, 408.

Gierer, A. \& Schramm, G. (1956). Infectivity of ribonucleic acid from tobacco mosaic virus. Nature, Lond. 177, 702.

Martin, W. B. \& Chapman, W. G. (1961). The tissue culture test for assaying the virus and neutralizing antibody of foot-and-mouth disease and its application to the measurement of immunity in cattle. Res. vet. Sci. $2,53$.

Nakamura, M. (1961). A comparison of the yields of infectious ribonucleic acid from heated and ultraviolet irradiated mouse encephalomyelitis virus (GD VII strain). J. Immunol. 87, 530.

Sellers, R. F. (1955). Growth and titration of the viruses of foot-and-mouth disease and vesicular stomatitis in kidney monolayer tissue cultures. Nature, Lond. 176, 547.

SkrnNer, H. H. (1951). Propagation of strains of foot-and-mouth disease virus in unweaned white mice. Proc. R. Soc. Med. 44, 1041. 